\title{
Tourist Attraction Potential Around the Cemetery of Sunan Kudus based on Social Media Analysis
}

\author{
Wahyu Septiana \\ Department of Architecture \\ Institut Teknologi Sepuluh Nopember \\ Surabaya, Indonesia
}

\author{
Eko Budi Santoso \\ Department of Urban and Regional Planning \\ Institut Teknologi Sepuluh Nopember \\ Surabaya, Indonesia
}

\author{
Haryo Sulistyarso \\ Department of Urban and Regional Planning \\ Institut Teknologi Sepuluh Nopember \\ Surabaya, Indonesia
}

\begin{abstract}
The Old Town of Kudus area has a main tourist attraction, the Menara Minaret and al-Aqsa Mosques and the Sunan Kudus Tomb, which is one of the destinations of the community pilgrimage. However, at this time only the Menara Minaret and al-Aqsa Mosques and Sunan Kudus Tombs that have been developed to be the tourist attractions. To identify potential tourist attractions around this area, it can be done by looking at the traces of visitor activity seen from social media. This social media use can reveal tourists' attitudes and interests in a tourist location.

This study was conducted using media content analysis techniques to find out the interests of visitors by looking at uploads on social media Instagram using hastag or the keyword Menara Kudus. Identification is done by looking at the highest number of uploads and information on each upload in certain spots around the Sunan Kudus Dining Area. The results of this study are that there are 4 tourist attractions, namely the Tower Mosque Complex and Sunan Kudus Cemetery, Jalan Menara Corridor, Jalan Madurekso Corridor and Kudus Traditional House. The tourist point of interest in uploading on Instagram social media is mostly in terms of architecture.
\end{abstract}

Keywords-Tourist Attraction, Visitors, Sosial Media, Religious Tourism

\section{INTRODUCTION}

Historical area as a cultural heritage is one of the valuable legacies of the past because the existence of historical buildings and their environmental characteristics illustrate the history of a place or region and reflect changes in the course of time and the way of life and culture of its inhabitants [1]. One of the historical areas in Indonesia that has tourism potential is the City of Kudus which has a history as one of the places for the spread of Islam on Java.

Kudus City is synonymous with the City of Santri or the City of Islam, since its establishment was part of a series of spreads of Islam in Java and developed into a center of knowledge and development of Islam in Java and even the archipelago [2]. The development embryo of Kudus City is located around the Menara Minaret and al-Aqsa Mosques, including the Kauman Village, Kejasan Village and
Langgardalem Village. Geographically, this old city borders Sungai Gelis to the east, Jl. Kiai Haji Asnawi in the west, Jl. JH Ahmad Dahlan in the north, Jl. Sunan Kudus in the south and in the central part of this area is divided by $\mathrm{Jl}$. Menara. This Menara Minaret and al-Aqsa Mosques is the center of the environment in the area of the Old Town.

This area of the Old Town of Kudus has a great potential for cultural tourism attraction to be developed because it has interesting attractions. The Menara Kudus Mosque or Al-Aqsa Mosque which is the center of the Old Town has a characteristic architecture with a unique cultural blend between Islamic culture and Hindu culture [3]. Besides that, there is also the Sunan Kudus Cemetery complex which is located on the west side of the Mosque and is one of the destinations of the community pilgrimage. It is known that the number of visitors to the Menara Kudus Mosque and the Cemetery of Sunan Kudus has experienced a significant increase in recent years. In the last 4 (four) years, the number of visitors in the Cemetery of Sunan Kudus area has experienced a significant increase.

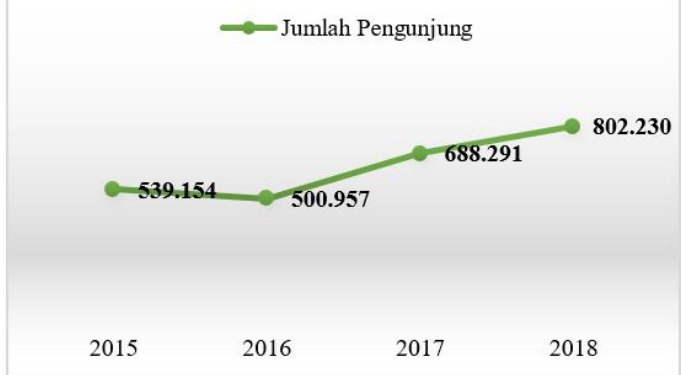

Fig. 1. Sunan Kudus Cemetery Number of Visitors from Years 2015-2018

It is known that the number of visitors to the Cemetery of Sunan Kudus in 2015 reached 539,154 people, then in 2016 experienced a slight decline with the number of visitors 500,957 people, then in the following year it increased until 2018 the number of visits reached 802,230 people. This proves that community interest in Indonesia towards religious tourism has also increased from year to year [4]. 
The development of tourism in the Old Town of Kudus area is still focused on the Menara Minaret and al-Aqsa Mosques and the Cemetery of Sunan Kudus. To maximize the potential of tourist attraction in the region, there needs to be other tourist attractions that can be developed into tourist destinations. Identification of tourist attractions around the Cemetery of Sunan Kudus can be done by looking at traces of community activities on the internet. The trend of internet usage in Indonesia has increased every year. In 2018 there were around 100 million active users and were dominated by the use of mobile internet [5]. One of the biggest uses of mobile internet is social media. Today social media is often used in expressing interesting locations, especially tourist locations. From the use of social media, it can be seen traces of user activity. It can also reveal tourists' attitudes and interests in a tourist location. In this study the use of social media was carried out to identify potential tourist attractions around the Sunan Kudus Cemetery based on tourist uploads.

\section{METODHOLOGY}

\section{A. Data Analysis Method}

The analytical method used in identifying potential tourist sites around Sunan Kudus Cemetery is to use Media Content Analysis. Content Analysis Media is done using social media which can be seen from hastag or keywords. Social media is an important tool for analyzing tourist behavior and this is confirmed by increased purchases and recommendations to other users. Social media that can be used in this research are Instagram with hastag or keyword Menara Kudus. Identification is done by looking at the highest number of uploads and point of interest in each upload in certain spots around the Sunan Kudus Dining Area. The visitor's point of interest can be seen from the caption or statement in each upload and then interpreted into several themes according to their respective contexts.

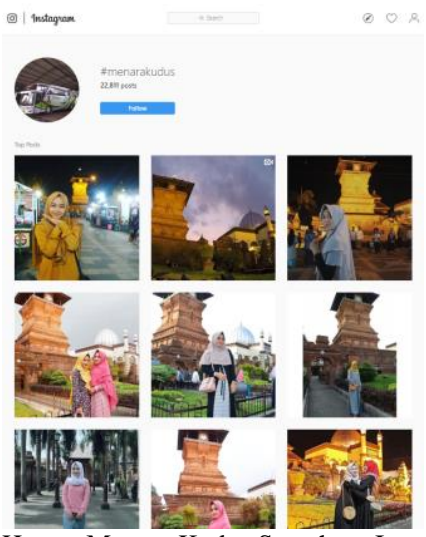

Fig. 2. Example of Hastag Menara Kudus Search on Instagram Social Media

\section{RESUlt AND DisCUSSION}

Identification of potential tourist locations around the Sunan Kudus Cemetery is done by media content analysis. Content analysis media is one of the fastest growing analytical techniques in the last 20 years [6]. Media content analysis was introduced as a systematic method for studying mass media by Harold Lassweell in 1927 which was initially used to study propaganda [7]. Macnamara (2011) explained that media content analysis became increasingly popular as a research methodology during the 1920s and 1930s to research the rapidly developing content of film communication.
Data collection for media content analysis is done using social media which can be seen from the hastag or keywords. Social media is an important tool for analyzing tourist behavior and this is confirmed by increased purchases and recommendations to other users. Social media that can be used in this research is Instagram with the hastag Menara Kudus. Identification is done by looking at the highest number of uploads in certain spots around the Sunan Kudus Cemetery and analyzing the context of the captions used as reasons for location removal.

The mapping process of tourism potential locations carried out with Content Analysis Media using Instagram social media with the Menara Kudus hastag is conducted for 1 year, starting on February 27, 2018 to February 26, 2019. The number of posts that have been analyzed is 7,969 with 3,347 corresponding posts. While the number of inappropriate posts is 4,622 . This appropriate post is showing the locations around the Menara Tower and Sunan Kudus Cemetery.

Based on data recording carried out, there are 9 (nine) points of location that are much in demand by visitors. The following are locations that are in great demand by visitors and uploaded on social media that have the potential to become potential tourist sites around the Sunan Kudus Cemetery.

TABLE 1. Spot which Visitors Interested with, based on Social Media

\begin{tabular}{|c|l|c|r|}
\hline No & \multicolumn{1}{|c|}{ Location } & Total & Likes \\
\hline 1 & Kudus Tower & 2.630 & 98.459 \\
\hline 2 & Al-Aqsa Mosque & 212 & 77.164 \\
\hline 3 & Jalan Menara Corridor & 199 & 67.421 \\
\hline 4 & Cemetery Court & 150 & 15.137 \\
\hline 5 & Sunan Kudus Tomb & 57 & 3.639 \\
\hline 6 & Padureksan Gate & 45 & 9.527 \\
\hline 7 & Jalan Madurekso Corridor & 35 & 2.704 \\
\hline 8 & Kudus Traditional House & 14 & 448 \\
\hline 9 & Kembar Gate & 5 & 132 \\
\hline
\end{tabular}

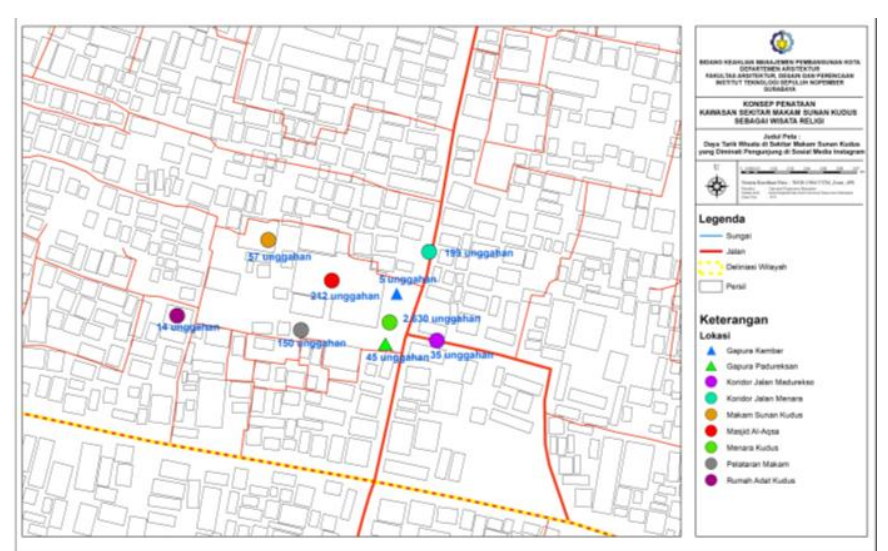

Fig. 3. Distribution of Tourism Attractions Around the Cemetery of Sunan Kudus, Attracted by Visitors on Social Media Instagram

The visitor's point of interest can be seen from the caption or description in each upload. The following is a summary of the results of content analysis from visitor uploads which are then interpreted in several themes. 


\begin{tabular}{|c|c|c|c|}
\hline No & $\begin{array}{c}\text { Tourist } \\
\text { Attraction }\end{array}$ & Visitor Information & Interpretation \\
\hline \multirow[t]{3}{*}{1} & \multirow[t]{3}{*}{ Kudus Tower } & $\begin{array}{l}\text { - "Bedhug \& kentongan ukiran } \\
\text { JAWA, artefak keramik } \\
\text { CHINA, arsitektur HINDU, } \\
\text { landmarks ISLAM, islam } \\
\text { yang DAMAI." } \\
\text { - The entrance to the uniquely } \\
\text { beautiful architecture of the } \\
\text { Hindu-Buddhist-influenced } \\
\text { Majapahit Empire-styled } \\
\text { three-tiered red brick tower } \\
\text { of the Menara Minaret and } \\
\text { al-Agsa Mosques of Kudus." }\end{array}$ & Architectural \\
\hline & & $\begin{array}{l}\text { "Bangunan luar biasa ini } \\
\text { menjadi bukti, betapa besar hati } \\
\text { para wali saat menyebarkan } \\
\text { Islam di Nusantara. Bangunan } \\
\text { masjid yang terkulturasi budaya } \\
\text { hindu, adalah ekspresi nyata apa } \\
\text { itu \#toleransi dan menerangkan } \\
\text { bahwa agama adalah } \\
\text { kedamaian" }\end{array}$ & Historical \\
\hline & & $\begin{array}{l}\text { - "gak bisa move on sama } \\
\text { tempat ini :) berjuta } \\
\text { kenangan tersimpan dalam } \\
\text { senyuman... Kudus have } \\
\text { story... Menara kudus .... } \\
\text { Taken by @bintang_287" } \\
\text { - "kenangan di bawah langit } \\
\text { menara" }\end{array}$ & Memories \\
\hline \multirow[t]{2}{*}{2} & \multirow{2}{*}{$\begin{array}{l}\text { Al-Aqsa } \\
\text { Mosque }\end{array}$} & "inside masjid al aqsho, kudus" & Architectural \\
\hline & & $\begin{array}{l}\text { "Masjid Al Aqsa Manarat } \\
\text { Qudus This is one of the oldest } \\
\text { mosque in Java and in } \\
\text { Indonesia, built in mid 16th } \\
\text { century" }\end{array}$ & Historical \\
\hline \multirow[t]{2}{*}{3} & \multirow[t]{2}{*}{$\begin{array}{l}\text { Jalan Menara } \\
\text { Corridor }\end{array}$} & $\begin{array}{l}\text { "zaman dulu, hampir tiap kamis } \\
\text { kalau mau ziarah ya lewat sini. } \\
\text { Tapi ya dulu nggak pernah } \\
\text { mikir bahwa ternyata gang ni } \\
\text { bagus buat tempat foto", }\end{array}$ & Arsitektural \\
\hline & & $\begin{array}{l}\text { "fajar mendung di jalan menara } \\
\text { kudus" }\end{array}$ & Atmosphere \\
\hline \multirow[t]{2}{*}{4} & \multirow[t]{2}{*}{$\begin{array}{l}\text { Cemetery } \\
\text { Court }\end{array}$} & $\begin{array}{l}\text { - "Anjungan menara kudus" } \\
\text { - "gerbangception. Ini adalah } \\
\text { gerbang atau pintu masuk } \\
\text { menuju makam sunan kudus } \\
\text { dimana batu2 dan } \\
\text { bangunannya masih asli dari } \\
\text { saat dulu dibangun" }\end{array}$ & Architectural \\
\hline & & $\begin{array}{l}\text { "Ngopa ngopi ngopa ngopi, } \\
\text { yooook ngaji iarah ziarah wisata } \\
\text { religi dino jumat iku akehno } \\
\text { sholawat nabi , ben selamat } \\
\text { donyo akherat", }\end{array}$ & $\begin{array}{l}\text { Pilgrimage/ } \\
\text { praying }\end{array}$ \\
\hline \multirow[t]{2}{*}{5} & \multirow[t]{2}{*}{$\begin{array}{l}\text { Sunan Kudus } \\
\text { Tomb }\end{array}$} & $\begin{array}{l}\text { "perjalananku berakhir di } \\
\text { makam sunan Kudus salah satu } \\
\text { wali songo di kotanya yang } \\
\text { memiliki menara kudus tanpa } \\
\text { semen, termasuk salah satu } \\
\text { kuasa Allah yang diberi kepada } \\
\text { hamba-Nya yang mulia dan } \\
\text { sholeh." }\end{array}$ & Architectural \\
\hline & & $\begin{array}{l}\text { "buka luwur merupajan upacara } \\
\text { penggatian kain kelambu } \\
\text { penutup makam yang } \\
\text { berlangsung tiap tahun" }\end{array}$ & Event \\
\hline 6 & $\begin{array}{l}\text { Padureksan } \\
\text { Gate }\end{array}$ & $\begin{array}{l}\text { "berziarah ke masjid menara } \\
\text { kudus dan makam sunan kudus" }\end{array}$ & $\begin{array}{l}\text { Pilgrimage/ } \\
\text { praying }\end{array}$ \\
\hline 7 & $\begin{array}{l}\text { Jalan } \\
\text { Madurekso } \\
\text { Corridor }\end{array}$ & $\begin{array}{l}\text { - "suasana adzan magrib di } \\
\text { menara kudus" } \\
\text { - "Sedikit senja di sekitar kota } \\
\text { Kudus" }\end{array}$ & Atmosphere \\
\hline 8 & $\begin{array}{l}\text { Kudus } \\
\text { Tradisional }\end{array}$ & $\begin{array}{l}\text { "Rumah adat Kudus atau biasa } \\
\text { disebut rumah Joglo Kudus. } \\
\text { Memiliki genteng yang unik }\end{array}$ & Historical \\
\hline
\end{tabular}

\begin{tabular}{|c|l|l|l|}
\hline No & \multicolumn{1}{|c|}{$\begin{array}{c}\text { Tourist } \\
\text { Attraction }\end{array}$} & \multicolumn{1}{|c|}{ Visitor Information } & Interpretation \\
\hline & House & $\begin{array}{l}\text { dinamakan "Atap Pencu". } \\
\text { Selain itu menemukan pula } \\
\text { Masjid Menara Kudus yang } \\
\text { sangat terkenal dengan simbol } \\
\text { akulturasi budaya Islam, Hindu, } \\
\text { tionghoa" }\end{array}$ & \\
\hline 9 & Kembar Gate & $\begin{array}{l}\text { "Siapa sangka bangunan } \\
\text { bernuansa hindu berada di } \\
\text { dalam Masjid, ya ini adalah } \\
\text { masjid Kudus" Architectural }\end{array}$ & \\
\hline
\end{tabular}

The points of interest of each location that are of interest to visitors are as follows:

\section{a. Kudus Tower}

Menara Kudus is located in Kauman Village, Kota Kudus District, Kudus Regency, Central Java. Menara Kudus is located in the southeast of the yard and faces west of the mosque complex area or the Sunan Kudus Cemetery complex which is surrounded by houses. In terms of architecture, the shape of the tower is similar to the shape of the temple in East Java. This is based on the history of architecture in the early periods of the development period of Islam in East Java, namely the Hindu period which ended the period of the rule of Majapahit which fell both for architecture and decoration patterns [8].

From the results of media content analysis that has been carried out there are several types of reasons for visitors to take photos at this location or point of interest seen from the captions or comments from the photo when posted on social media. From the results of the analysis it was concluded that there were 7 (seven) contexts written in the photo upload of the Kudus Tower. Most of the points of interest are in terms of the unique architecture of the Kudus Tower and become an attractive spot for visitors. The following are the conclusions of the location of the Kudus Tower.

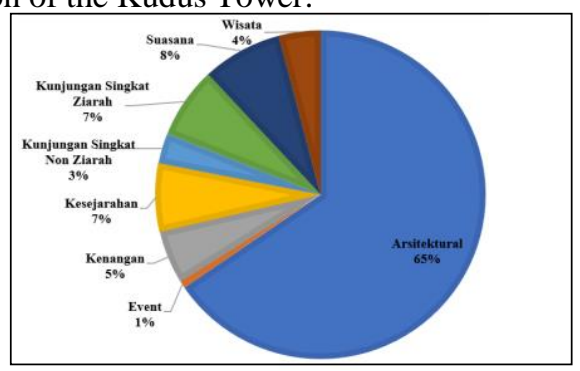

Fig. 4. Point of Interest from Menara Kudus

From the results of the analysis it is known that the most context is in terms of architectural Menara Kudus with a percentage of $65 \%$, then the second is atmosphere, pilgrimage visits and historical symbols with a percentage of $8 \%$ and $7 \%$ respectively.

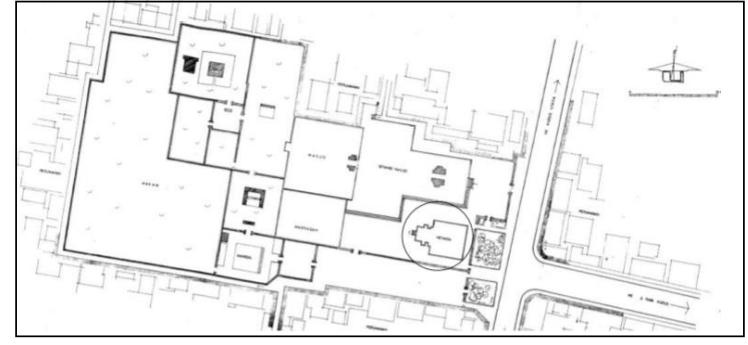

Fig. 5. Plan of Location of the Kudus Tower in the Sunan Kudus Tomb Complex 
The Kudus Tower is an ancient building as a result of acculturation between Hindu-Javanese culture and Islam, even elements of indigenous culture. Jasper said that the art of bias or carvings from the buildings of the Menara Kudus showed a refined artistic tradition from the Majapahit Javanese Hindu building. Sucipto Wirjosuparto connects the shape of the Menara Minaret with Jago Temple. This can be seen very much in the tumpal ornament on a ladder arrangement similar to that in Jago Temple. The visible element of Islam is a simple ornament. While the original Indonesian element appears in the decoration of the spill. The tumpal decoration motif has been around since pre-historic times in Indonesia.

Kudus Tower consists of the foot of the tower which has three temples arranged together. Then the body part of the tower, which is divided into two, namely the lower part which is a large and tall temple divided in two by a thick frame, a slender rectangular center body which is slim and the upper tower body consists of horizontal seams to the more the top gets longer and wider. The top of the tower is in the form of a hall like a pavilion with a board.
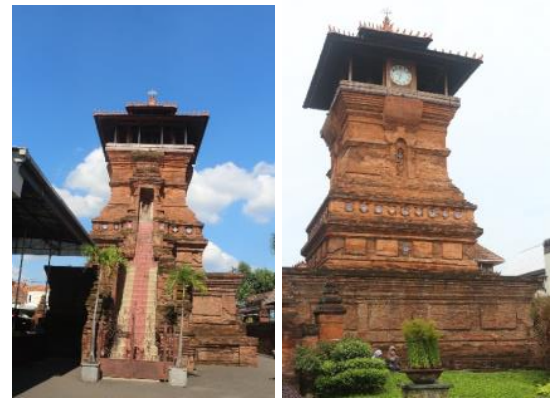

Fig. 6. The Kudus Tower Front View and Rear View

\section{b. Al-Aqsa Mosque}

Sunan Kudus established the Menara Mosque with the name Loaram which was later converted to Al-Manar or AlAqsa Mosque which took the name of the mosque in Palestine. Al-Aqsa Mosque has an area of 1,723.84 $\mathrm{m}$ which was built on an area of $6,325 \mathrm{~m}$. The year of the construction of the written tower in the Javanese sengkala literary chronicle reads "Ewahing Jagat Damaged Archway" which means in $1609 \mathrm{~J} / 1687$ M. On November 5, 1933 the expansion of the AlAqsa Mosque's porch was carried out. The renovation of the pawastren (for female prayers) was carried out in 2011 and the renovation of tajug was carried out in 2013

From the results of media content analysis that has been carried out there are several types of reasons for visitors to take photos at this location or point of interest seen from the captions or comments from the photo when posted on social media. From the results of the analysis it was concluded that there were 5 (five) contexts written in the photo upload of the Al-Aqsa Mosque. Most of the points of interest are in terms of architectural unique Al-Aqsa Mosque and become one of the interesting spots for visitors. The following are the conclusions from the location of the Al-Aqsa Mosque.

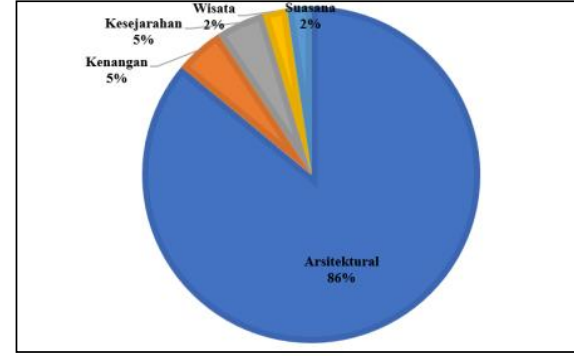

Fig. 7. Point of Interest of Al-Aqsa Kudus Mosque

From the results of the analysis it is known that the most point of interest is in terms of architectural Al-Aqsa Mosque with a percentage of $86 \%$, then the second is memories and history with a percentage of $5 \%$.

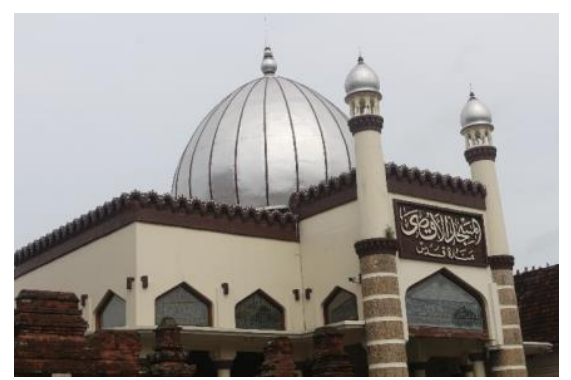

Fig. 8. Al-Aqsa Mosque in Tower Mosque Complex and Sunan Kudus Cemetery

\section{c. Jalan Menara Corridor}

Jalan Menara Corridor has its architectural potential which is one of the photo spots for visitors. This architectural potential is a distinctive feature of the settlement of the Old Town of Kudus in colonial and Javanese style.

From the results of media content analysis that has been carried out there are several types of reasons for visitors to take photos at this location or point of interest seen from the captions or comments from the photo when posted on social media. From the results of the analysis it was concluded that there were 6 (six) contexts written in the photo upload of $\mathrm{Jl}$. Menara Corridor Most of the points of interest are in terms of architectural $\mathrm{Jl}$. Menara Corridor is unique and becomes one of the interesting spots for visitors. The following are the conclusions of the $\mathrm{Jl}$. Menara Corridor.

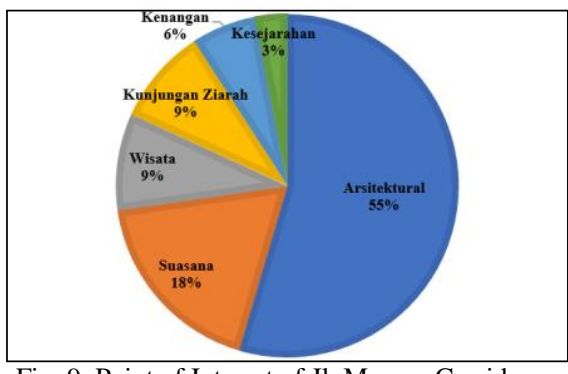

Fig. 9. Point of Interest of Jl. Menara Corridor

From the results of the analysis it is known that the most point of interest is in terms of architectural $\mathrm{Jl}$. Menara Corridor with a percentage of $55 \%$ because in this corridor there are many old houses and sacred traditional houses that have unique characteristics, then the second is the atmosphere of $18 \%$ and the third is tourism and pilgrimage visits with $9 \%$ each. 


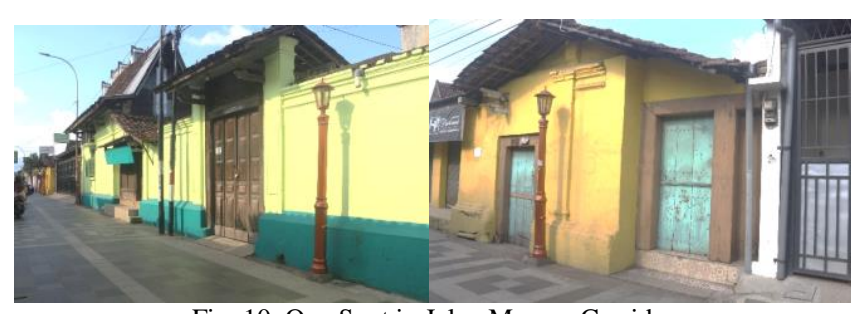

Fig. 10. One Spot in Jalan Menara Corridor

\section{d. Cemetery Court}

The court of the cemetery is the parts that visitors must pass before entering the main tomb, the Tomb of Sunan Kudus. In the courtyard of this cemetery there are cemetery of relatives of Sunan Kudus. In addition, there is also a pavilion which is a place for recitation and lectures on Sunan Kudus and twin wells that are commonly used by pilgrims to purify pilgrims before entering the cemetery area.

From the results of media content analysis that has been carried out there are several types of reasons for visitors to take photos at this location or point of interest seen from the captions or comments from the photo when posted on social media. From the results of the analysis it was concluded that there were 5 (five) contexts written in the photo upload of the Graveyard. Most of the points of interest are in terms of architectural unique Tomb Court and become one of the interesting spots for visitors. The following are the conclusions from the location of the Cemetery Court.

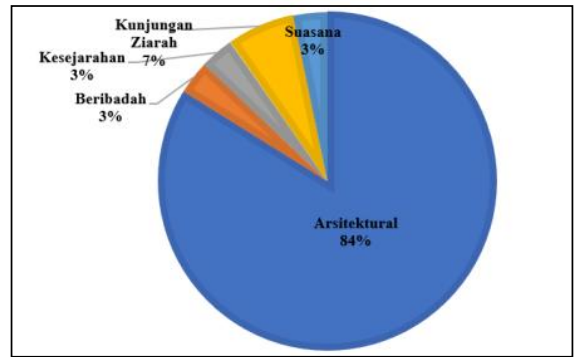

Fig. 11. Point of Interest of Cemetery Court

From the results of the analysis it is known that the most point of interest is in terms of architectural location around the tomb court with a percentage of $84 \%$, then the second is a pilgrimage visit of 75 and the third is worship, history and atmosphere with a percentage of $3 \%$.

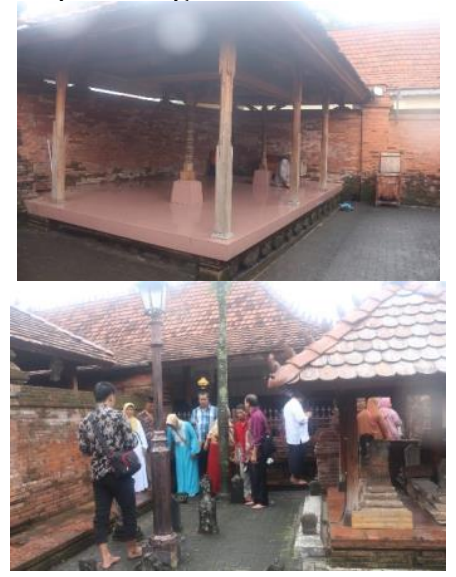

Fig. 12. Location of Sunan Kudus Cemetery Court

\section{e. Sunan Kudus Tomb}

The tomb of Sunan Kudus is located at the back of the Menara Tower and Sunan Kudus Cemetery. The tomb of
Sunan Kudus is $225 \mathrm{~cm}$ long, $70 \mathrm{~cm}$ wide and $40 \mathrm{~cm}$ wide made of stone and cement. In this tomb there is a tombstone that has a height of $48 \mathrm{cn}$ and a width of $14 \mathrm{~cm}$. The tomb of Sunan Kudus is protected with a cupola and given a white mosquito net and a door with carved teak. This mosquito net is always replaced on the 10th of the Sura, known as the Buka Luwur tradition [9].

From the results of media content analysis that has been carried out there are several types of reasons for visitors to take photos at this location or point of interest seen from the captions or comments from the photo when posted on social media. From the results of the analysis it was concluded that there were 3 (three) contexts written in the photo upload of the Sunan Kudus Tomb. Most of the points of interest are in the architectural terms of the unique Sunan Kudus Tomb and become an attractive spot for visitors. The following are the conclusions of the location of the Sunan Kudus Tomb.

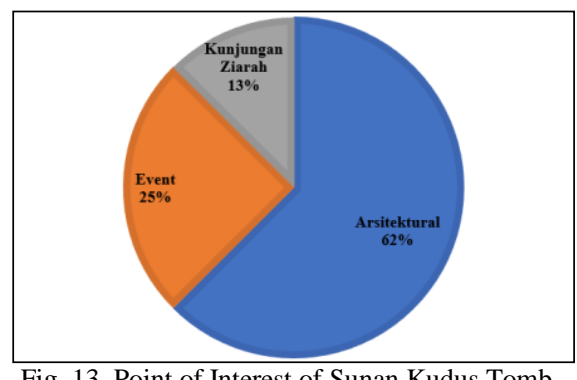

From the results of the analysis it is known that the most point of interest is in terms of architectural Sunan Kudus Tomb with a percentage of $62 \%$, then the second is the event that is equal to $25 \%$ and the third is a pilgrimage visit of $13 \%$.

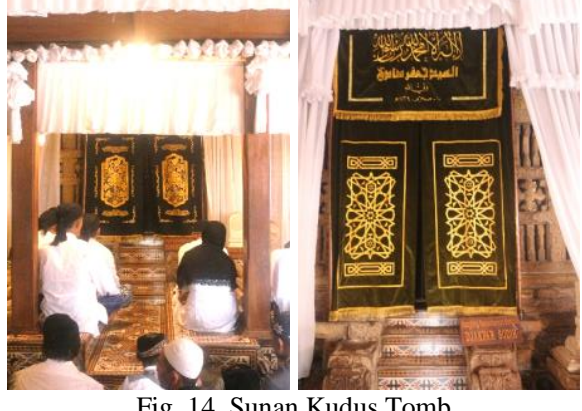

Fig. 14. Sunan Kudus Tomb

\section{f. Padureksan Gate}

Padureksan Gate is one of the sites in the Kudus Tower complex. The gate which is located south of the Kudus Tower is considered sacred when viewed from its history. Padureksan gate is $617 \mathrm{~cm}$ long, $189 \mathrm{~cm}$ wide and $489 \mathrm{~cm}$ high, $132 \mathrm{~cm}$ wide door and $220 \mathrm{~cm}$ high. The community has the belief that a lot of tattoo is stored at the entrance of the tajug tower. There is public trust if there is an official who passes through the gate so that his rank will disappear or fall.

From the results of media content analysis that has been carried out there are several types of reasons for visitors to take photos at this location or point of interest seen from the captions or comments from the photo when posted on social media. From the results of the analysis it was concluded that there were 4 (four) contexts written in the photo upload of the Padureksan Gate. Most of the points of interest are in terms of the unique architectural gate and become an attractive spot for 
visitors. The following are the conclusions from the location of the Padureksan Gate.

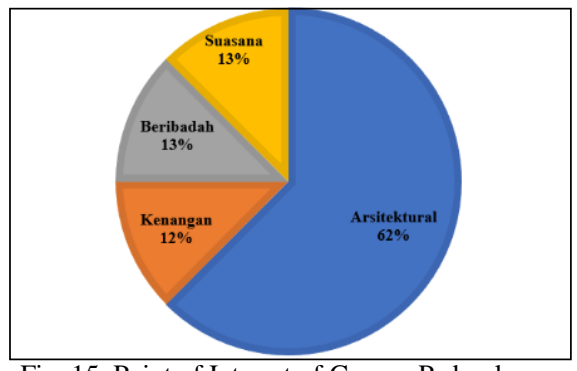

Fig. 15. Point of Interest of Gapura Padureksan

From the results of the analysis it is known that the most point of interest is in terms of architectural Padureksan Gate with a percentage of $62 \%$, then the second is worship and atmosphere with each percentage of $13 \%$.

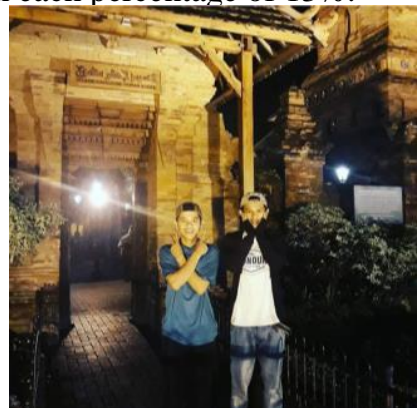

Fig. 16. Gapura Padureksan in Complex of Masjid Menara and Sunan Kudus Cemetery

\section{g. Jalan Madurekso Corridor}

The Jalan Madurekso Corridor is one of the roads that is the trade center of the people around the Sunan Kudus Tomb, especially souvenirs or souvenirs for pilgrims. Jl Madurekso is a road that connects the Masjid Menara and Sunan Kudus Tombs with Hok Liong Bio Temple which is located at one end of the Road. In addition, Jl Madurekso is also one of the accesses for pilgrims to enter the Masjid Menara and Sunan Kudus Tombs.

From the results of media content analysis that has been carried out there are several types of reasons for visitors to take photos at this location or point of interest seen from the captions or comments from the photo when posted on social media. From the results of the analysis, it was concluded that there were 3 (three) contexts written in the photo upload of Jl. Madurekso Corridor. Most of the points of interest are in terms of architectural Jl. Madurekso Corridor is unique and is one of the interesting spots for visitors. The following are the conclusions of the Jl. Madurekso Corridor location.

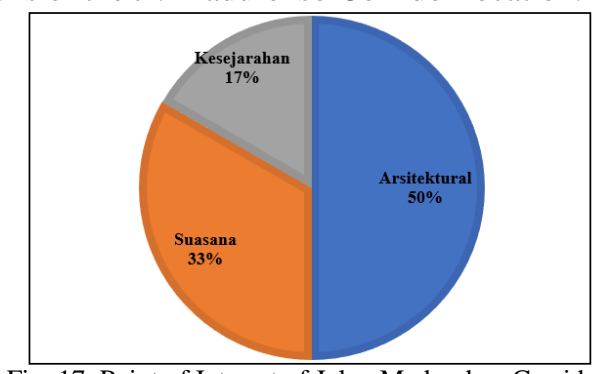

Fig. 17. Point of Interest of Jalan Madurekso Corridor

From the results of the analysis it is known that the most point of interest is in terms of architectural Corridor $\mathrm{Jl}$.
Madurekso with a percentage of $50 \%$, then the second is suasan which is equal to $33 \%$ and the third is historical by $17 \%$.

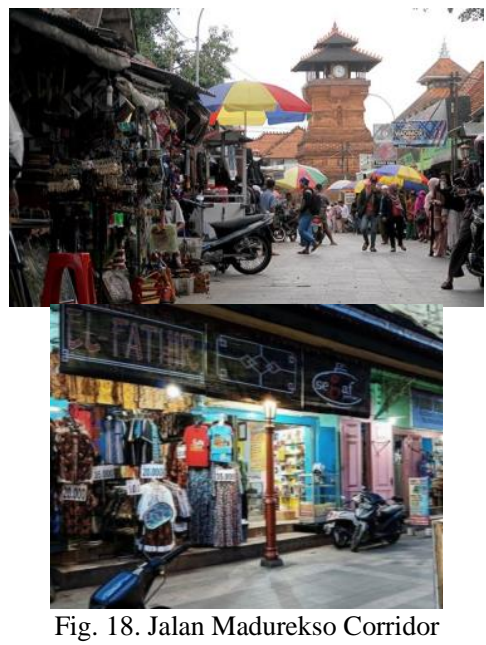

\section{h. Kudus Traditional House}

Kudus traditional house is part of Javanese architecture which has local characteristics typical of coastal Java. When compared with the Javanese house layout in the interior such as Jogja and Solo, the Kudus traditional house has some similarities in general, but also has interesting differences. These differences include the absence of pavilion and pringgitan spaces in Kudus traditional houses, instead there are jogosatru as development of Javanese house terraces [10]. The Kudus community used to call it Omah Pencu because it has a towering roof, unlike most houses.

From the results of media content analysis that has been carried out there are several types of reasons for visitors to take photos at this location or point of interest seen from the captions or comments from the photo when posted on social media. From the results of the analysis, it is concluded that there is 1 (one) context written in the Corridor photo upload, namely in terms of its history. The Kudus Traditional House has a unique characteristic and has a history in the traditional architecture of Kudus.

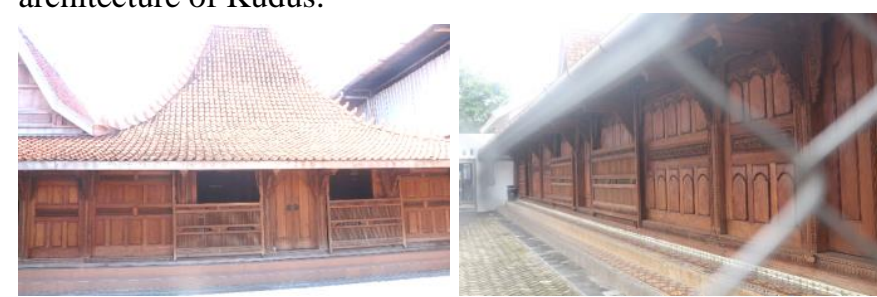

Fig. 19. Kudus Traditional House

\section{i. Kembar Gate}

This Kembar Gate is located on the outer porch and inside the Al-Aqsa Mosque. This gate has a Hindu gata which was once a fortress of a mosque in the era of guardianship. The Kembar Gate that is inside the mosque is the entrance to the mosque in ancient times. The materials used in this Kembar Gate are red bricks, shingles and brick adhesives with a breezy arrangement of stones, legs, body and roof [11]. Until now this Kembar Gate still stands firmly on the porch of the mosque and inside the mosque.

From the results of media content analysis that has been carried out there are several types of reasons for visitors to take photos at this location or point of interest seen from the 
captions or comments from the photo when posted on social media. From the results of the analysis, it is concluded that there is 1 (one) context written in uploading photos of the Kembar Gate, in terms of architecture.

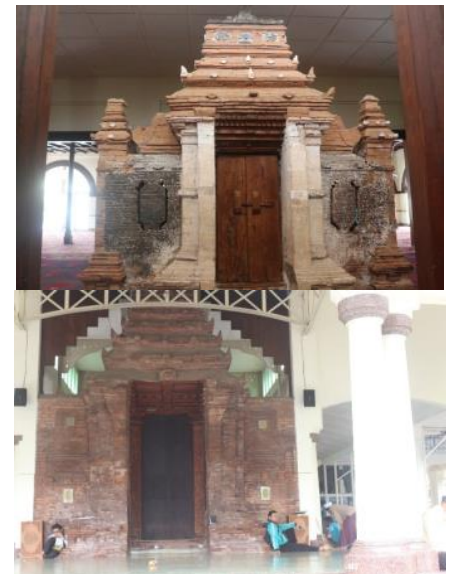

Fig. 20. Kembar Gates which are in the Mosque's Porch and Inside the AlAqsa Mosque Kudus

\section{CONCLUTION}

Based on the results of the social media content analysis that has been done, it can be concluded that there are 9 (nine) potential tourist attractions around the Sunan Kudus Tomb that are in great demand by tourists or visitors. The conclusion is seen from the upload of tourists on Instagram social media using the sacred tower hastag. The 9 (nine) potential tourist attractions are the Kudus Tower, Al-Aqsa Mosque, Padureksan Gate, Cemetery Court, Sunan Kudus Tomb, Jl. Menara Corridor, Jl. Madurekso Corridor, Kembar Gate and Kudus Traditional House.

6 (six) potential tourist attractions obtained from tourist uploads on Instagram social media within the Menara and Sunan Kudus Cemetery Mosque complex, namely the Kudus Tower, Al-Aqsa Mosque, Padureksan Gate, Court of the Tomb, Sunan Kudus Tomb and Twin Gapura. Based on this, the potential location of tourist attractions around the Sunan Kudus Cemetery is grouped into 4, namely, the Menara Minaret and Al-Aqsa Mosque Complex and the Tomb of Sunan Kudus, J1. Menara Corridor, Jl. Madurekso Corridor and Kudus Traditional House. The tourist point of interest in uploading on Instagram social media is mostly in terms of architecture.

\section{ACKNOWLEDGMENT}

The author would like to thank Mrs. Lilik, Head of the History, Permission and Antiquities Section of the Kudus Regency Tourism and Culture Office, Mr Sugito Secretary of the Langgar Dalem Village, Mr. Gatot the Kejasan Village Head and Ms. Niken Staff the Kauman Village Office, Kudus District as the resource person who gave information and references for this study.

\section{REFERENCES}

[1] Nurini. (2011). Kajian Pelestarian Kampung Kauman Kudus sebagai Kawasan Bersejarah Penyebaran Agama Islam. Jurnal Teknik Universitas Diponegoro Vol. 32 (1) pp. 9-17

[2] Sardjono, Agung Budi. (2009). Permukiman Masyarakat Kudus Kulon. Universitas Diponegoro.

[3] Pradisa, Andita Pupita Sari. (2017). Perpaduan Budaya Islam dan Hindu dalam Masjid Menara Kudus. Prosiding Seminar Heritage IPLBI 2017 pp. A213-218

[4] Badan Pusat Statistik. (2017). Kabupaten Kudus Dalam Angka. Kabupaten Kudus

[5] Untari, Dwi and Dewi Endah Fajariana. (2018). Strategi Pemasaran Melalui Media Sosial Instagram (Studi Deskriptif pada Akun @Subur_Batik). Jurnal Sekretari dan Manajemen Vol. 2 (2) pp. 271 278

[6] Neuendorf, K.A. (2002). The Content Analysis Guidebook. Thousand Oaks: Sage Publications.

[7] Macnamara, Jim. (2011). Media Content Analysis: Its Uses; Benefit and Best Practice Methodology. Asia Pasific Public Relations Journal, Vol. 6(1) pp. 1-34

[8] Syafwandi. (1985). Menara Mesjid Kudus dalam Tinjauan Sejarah dan Arsitektur, Jakarta: Bulan Bintang.

[9] Dinas Kebudayaan dan Pariwisata Kabupaten Kudus. (2012). Inventarisasi Pelestarian Pengelolaan Cagar Budaya Kabupaten Kudus. Kabupaten Kudus.

[10] Sudarwanto, Budi and Bambang Adji Murtomo. (2013). Studi Struktur dan Konstruksi Bangunan Tradisional Rumah 'Pencu' di Kudus. Jurnal Lingkungan Binaan Indonesia Vol. 2 (1) pp. 35-42

[11] Rosyid, Moh. (2018). Kawasan Kauman Menara Kudus sebagai Cagar Budaya Islam: Catatan Terhadap Kebijakan Pemerintah Kabupaten Kudus. Jurnal Penelitian dan Pengembangan Arkeologi Vol. 7(1) pp. 89-101 